colombiamedica.univalle.edu.co

Case report

\title{
Progression of peritoneal adenomucinosis to the scrotum: a rare occurrence treated with cytoreductive surgery and hyperthermic chemoperfusion of the scrotum in two patients
}

\section{Progresión de adenomucinosis peritoneal en el escroto de dos pacientes y tratamiento con cirugía citorreductora y quimioperfusión hipertérmica}

\author{
Armando Sardi ${ }^{* 1}$, William Andrés Jiménez ${ }^{2}$, Chukwuemeka Wosu²
}

1 Director and Chief of Surgical Oncology, Division of Surgical Oncology, The Institute for Cancer Care - Mercy Medical Center, Baltimore, Maryland, USA.

2 Research physician, Division of Surgical Oncology, The Institute for Cancer Care - Mercy Medical Center, Baltimore, Maryland, USA.

Sardi A, Jiménez WA, Wosu C. Progression of peritoneal adenomucinosis to the scrotum: a rare occurrence treated with cytoreductive surgery and hyperthermic chemoperfusion of the scrotum in two patients. Colomb Med. 2014; 45(2): 77-80.

(c) 2014 Universidad del Valle. This is an Open Access article distributed under the terms of the Creative Commons Attribution License, which permits unrestricted use, distribution, and reproduction in any medium, provided the original author and source are credited.

\section{Article history:}

Received: 12 August 2013

Accepted: 03 April 2014

Keywords:

Hyperthermic

DPAM, cytoreductive

surgery, CRS, HIPEC

Palabras clave:

Quimioperfusión

hipertérmica, escroto,

DPAM, cirugía

citoreductiva, CRS, HIPEC
Revised: 13 November 2013

chemoperfusion, scrotum,

\begin{abstract}
Introduction: Disseminated Peritoneal Adenomucinosis (DPAM) is an infrequent presentation of appendiceal cancer. Infrequently, umbilical or inguinal hernias could be the first clinical manifestation of this condition; DPAM extension to the scrotum may be anatomically viable. Treatment with cytoreductive surgery (CRS) and hyperthermic intraperitoneal chemotherapy (HIPEC) is the standard of treatment for DPAM. We hypothesize that these same treatment principles, consisting of CRS with hyperthermic chemoperfusion of the scrotum (HCS), could be applied to the scrotal dissemination of DPAM.

Methods: We reviewed our Institution's prospective cancer database and identified two cases of DPAM with extension to the scrotum. Their medical records were examined, and close followup was performed. Tumor histopathology and cytoreduction scores were evaluated. Tumor progression was monitored on follow-up by physical examination, tumor markers (CEA, CA 125, CA 19.9) and abdomino-pelvic CT scan.

Results: Two patients who previously had CRS/ HIPEC for DPAM were successfully treated with HSC. Both patients are alive and free of disease at 88 and 57 months following initial CRS/HIPEC, and 50 and 32 months following CRS/HCS, respectively.

Conclusion: Increased awareness by surgeons to the coexistence of inguinal hernia with peritoneal neoplasm and the need for a surgical repair is raised. CRS/HCS may be employed to treat patients with DPAM extension to the scrotum. Successful outcome is dependent on complete cytoreduction of metastatic tumor.
\end{abstract}

${ }^{\star}$ Corresponding author:

Director and Chief of Surgical Oncology, The Institute for Cancer Care - Mercy

Medical Center 227 St. Paul Place, Baltimore, Maryland, 21202-2001, USA

Tel: (1) (410)332-9294; Fax: (1) (410)332-9731.E-mail: asardi@mdmercy.com

\section{Resumen}

Introducción: La Adenomucinosis Peritoneal Diseminada (DPAM, por el término en inglés) es una presentación no frecuente del cáncer de apéndice. Infrecuentemente, las hernias umbilicales o inguinales pueden ser la primera manifestación clínica de esta condición; la extensión al escroto puede ser anatómicamente viable. La cirugía citoreductiva (CRS, por el término en inglés) con quimioterapia hipertérmica intraperitoneal (HIPEC, por el término en inglés) es el tratamiento estándar para DPAM. Nuestra hipótesis es que los mismos principios terapéuticos, consistentes en CRS con quimioterapia hipertérmica del escroto (HCS, por el término en inglés), pueden ser aplicados para DPAM con extensión al escroto.

Métodos: Revisamos una base de datos prospectiva en nuestra Institución donde se identificaron dos casos de DPAM con extensión al escroto. Se examinaron sus historias clínicas, y se realizaron controles cercanos. La histopatología tumoral y la citoreducción fueron evaluados. La progresión tumoral fue monitorizada en los controles mediante examen físico, marcadores tumorales (CEA, CA 125, CA 19.9) y TAC abdomino-pélvico.

Resultados: Dos pacientes a quienes se les practicó previamente CRS/ HIPEC por DPAM fueron exitosamente tratados con CRS/HSC. Ambos pacientes se encuentran vivos y sin evidencia de enfermedad 88 y 57 meses después de la CRS/HIPEC inicial y a 50 y 32 meses post CRS/HCS, respectivamente.

Conclusión: La precaución de los cirujanos sobre la coexistencia de hernias inguinales con neoplasias peritoneales y la necesidad de reparo quirúrgico debe ser incrementada. La CRS/HCS puede ser empleada en el tratamiento a pacientes con DPAM con extensión al escroto. Los resultados clínicos son dependientes de una citoreducción completa del tumor metastásico. 


\section{Introduction}

Disseminated peritoneal adenomucinosis (DPAM) is a common presentation of tumors arising from the appendix; it is frequently associated with extensive peritoneal involvement ${ }^{1,2}$. Its mucinous overproduction could trigger unspecific symptoms, challenging appropriate diagnosis. Initial clinical presentation may be characterized by only an inguinal and/or umbilical hernia filled with mucin. However, no clear diagnosis or treatment option has been proposed for the scrotal extension of DPAM.

Cytoreductive surgery (CRS) followed by hyperthermic intraperitoneal chemotherapy (HIPEC) has been recommended as a standard of care for patients with DPAM ${ }^{2-4}$, increasing long term survival up to $80 \%$ and $75 \%$ at 5 and 10 years, respectively ${ }^{5-7}$. We hypothesize that the involvement of a hernia sac, given that it is an extension of the peritoneum, could be treated similarly. We report two cases of DPAM with scrotal recurrence following successful CRS/HIPEC. The scrotal recurrence was treated with inguinal CRS and orchiectomy followed by hyperthermic chemoperfusion of the scrotum (HCS).

Hyperthermic chemoperfusion of the scrotum

Technique: Upon completion of CRS, two catheters (an inflow and outflow) were inserted into the groin. These catheters were secured temporarily with sutures (Fig. 1). While the inflow catheter extends into the scrotum, the outflow catheter remained proximal in the groin. Hyperthermic chemoperfusion of the scrotum was carried out by using $20 \mathrm{mg}$ of Mitomycin-C for $60 \mathrm{~min}$ with an inflow temperature maintained at $43^{\circ} \mathrm{C}$ and an outflow temperature of $41-42^{\circ} \mathrm{C}$.

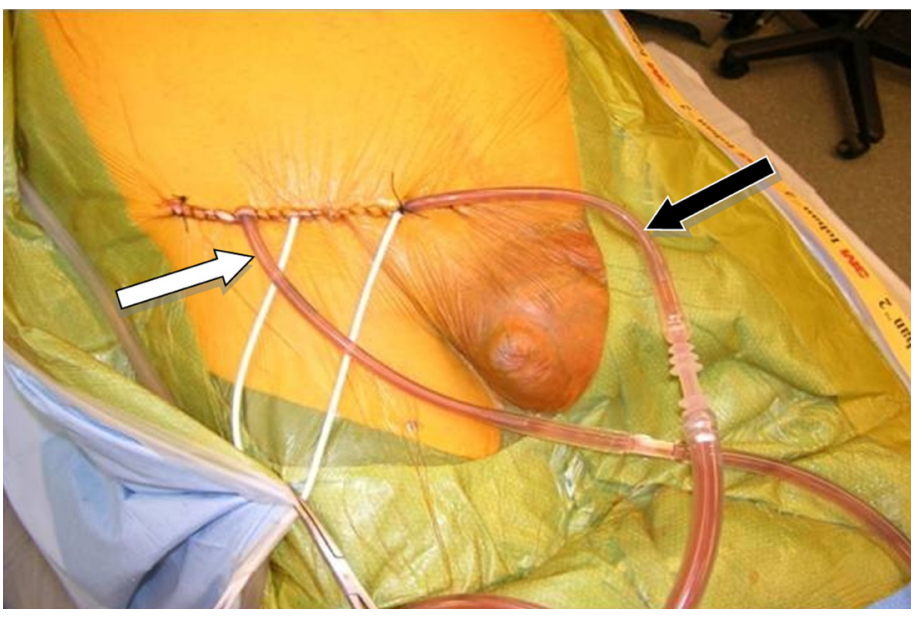

Figure 1. Hyperthermic chemoperfusion of the scrotum (HCS). Figure showing external view of the catheters placement during hyperthermic chemoperfusion to the scrotum at the right groin. Black arrow: Inflow catheter extending to the scrotum. White arrow: Outflow catheter extending to the proximal groin.

\section{Case \#1}

A 65-year-old male presented with an inguinal and incarcerated umbilical hernia. At the time of surgery, he had mucinous collection in the umbilical hernia sac. The procedure was converted to a laparotomy with an appendectomy and peritoneal biopsy. $\mathrm{He}$ required umbilical and inguinal herniorrhaphy, requiring mesh for the latter after excision of the hernia sac. Pathology revealed that the tissue specimen was consistent with mucinous cystadenoma of the appendix with pseudomyxoma peritonei - DPAM. A CT scan revealed multiple areas of mucinous collection around the liver and omental involvement of the tumor (Fig. 2a).
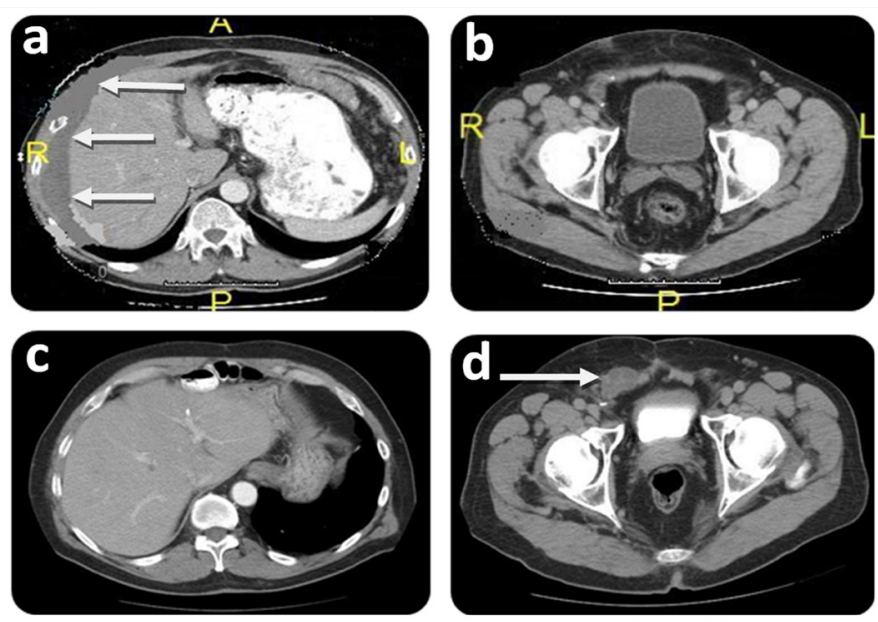

Figure 2. Initial and follow-up CT scan findings of Case \# 1. Preoperative: a- CT scan shows intraperitoneal mucin around liver (white arrows) at initial CRS/HIPEC. A: Anterior; P: Posterior; R: Right side; L: Left side. b- CT scan shows no groin involvement at initial CRS/ HIPEC. P: Posterior; R: Right side; L: Left side. Postoperative (36 months after CRS/HIPEC): cCT scan shows no evidence of disease within the peritoneal cavity at time of groin recurrence. d- CT scan showing groin mass recurrence extending into the scrotum (white arrow).

Two months later, the patient was referred to our center specializing on peritoneal surface malignancy. Following a detailed history, the groin was carefully examined and hernia recurrence was ruled out. The CT scan showed diffuse peritoneal implants. No tumor was seen in the groin (Fig. 2b). The patient underwent a CRS/HIPEC (closed technique) using $40 \mathrm{mg}$ of Mitomycin-C for $90 \mathrm{~min}(30 \mathrm{mg}$ given at time 0 and $10 \mathrm{mg}$ 30 min later) with an inflow temperature maintained at $43^{\circ} \mathrm{C}$ and an outflow temperature of $41-42^{\circ} \mathrm{C}$. The pre/post surgical peritoneal carcinomatosis index (PCI) was $32 / 0$, and complete cytoreduction (CC-0) was achieved. On post operative day 7, the patient developed pneumonia successfully treated with antibiotics and was discharged on post operative day 21 without further complications. He underwent close follow-up and 36 months after CRS/HIPEC, the patient complained of right scrotal edema and a right groin discomfort. No evidence of intraabdominal disease was evident on CT scan (Fig. 2c); however, and a right groin mass was identified (Fig. 2d). Mucin was obtained with a fine needle aspiration of the scrotum. At the diagnostic laparoscopy, a groin recurrence with extension to the scrotum was strongly suspected and intra-abdominal recurrence was ruled out. Two months later, the patient was subjected to exploration of the right groin with radical tumoral resection, resection of abdominal wall, orchiectomy, and HCS (Fig. 1). Complete cytoreduction was achieved. The patient was discharged on post operative day 5 without complication. On close follow-up, the patient is alive and with no evidence of disease (NED) 88 months from the first CRS/HIPEC, and 50 months from CRS/HCS. 


\section{Case \#2}

A 63-year-old male presented with right lower abdominal pain. Appendicitis was suspected and his appendectomy was converted to an exploratory laparotomy due to incidental findings of ruptured tumor of the appendix and DPAM. The patient required a right hemicolectomy at that time. Pathology showed ruptured mucinous cystadenoma of the appendix with pseudomyxoma peritonei - DPAM. Eleven months later, a left inguinal hernia was diagnosed and during the mesh herniorrhaphy peritoneal and hernial sac mucinous deposits were identified.

Five months after the herniorrhaphy, the patient was referred to our Institution with a complaint of right lower abdominal discomfort. Further evaluation with a CT scan showed diffuse peritoneal metastases (Fig. 3a). No groin disease was found on physical examination or CT scan (Fig. 3b). Three weeks later, the patient underwent a CRS/HIPEC for DPAM. The pre/post surgical PCI was 36/0 and a CC-0 was achieved. Hyperthermic intraperitoneal chemotherapy (closed technique) was carried out by using $40 \mathrm{mg}$ of Mitomycin-C for $90 \mathrm{~min}$ (30 mg given at time 0 and $10 \mathrm{mg} 30 \mathrm{~min}$ later) with inflow temperature maintained at $43^{\circ} \mathrm{C}$ and outflow temperature of $41-42^{\circ} \mathrm{C}$. Seven months later, on follow up, the patient presented with left groin discomfort and a scrotal mass. A CT scan identified no evidence of intraabdominal disease (Fig. 3c) and a left scrotal mass (Fig. 3d). Fineneedle aspiration determined the existence of mucin in the left scrotum. Two months later, the patient had CRS including left orchiectomy, removal of in-situ Prolene ${ }^{\circledR}$ mesh, HCS (Fig. 1), and subsequent repair of inguinal defect with Prolene ${ }^{\varpi}$ mesh. Complete cytoreduction was achieved at this stage. The patient was discharged on post-operative day 3 without complication. On follow-up, the patient is considered NED at 57 months after his initial CRS/HIPEC and 32 months post CRS/HCS.
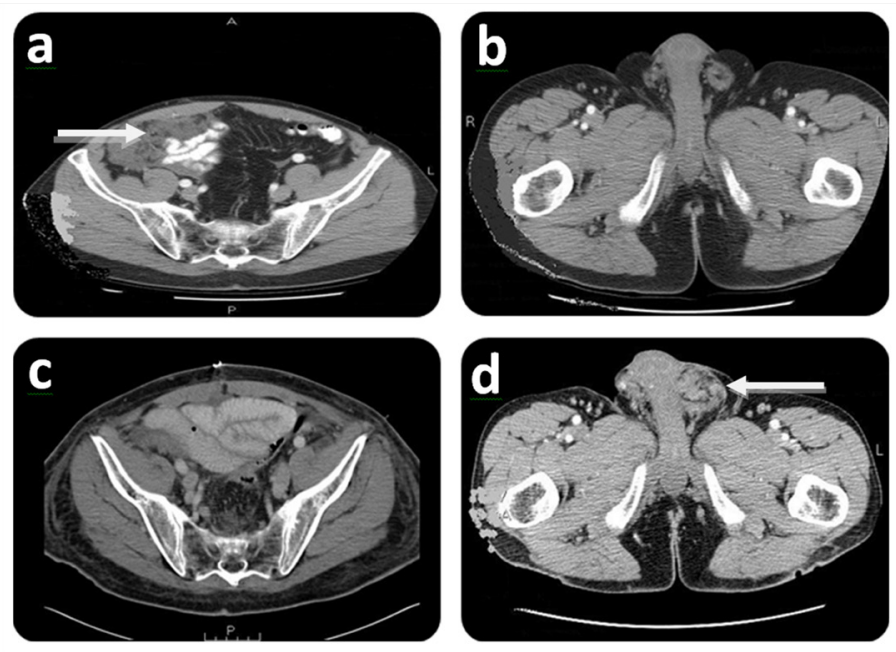

Figure 3. Initial and follow-up CT scan findings of Case \# 2. Preoperative: a- CT scan shows right lower abdominal mass (white arrow) at initial CRS/HIPEC. A: Anterior; P: Posterior. b- CT scan shows no groin involvement at initial CRS/HIPEC. R: Right side; L: Left side. Postoperative (7 months after CRS/HIPEC): c- CT scan shows no evidence of disease at time of scrotal recurrence. P: Posterior. d- CT scan showing left scrotal mass (white arrow). L: Left side.

\section{Discussion}

Peritoneal dissemination is a common presentation of appendiceal tumors regardless of the grade of histopathology ${ }^{4}$. An inguinal or umbilical hernia could be the first manifestation of this condition. Of historic interest, Sister Mary Joseph nodule is a palpable nodule bulging into the umbilicus as a result of metastases of a malignant cancer in the gastrointestinal tract or pelvis. Sister Mary Joseph Dempsey was the surgical assistant of William J. Mayo. She drew Mayo's attention to this phenomenon and, in 1949, Hamilton Bailey coined the term after her.

CRS/HIPEC is considered the standard of care for DPAM with complete cytoreduction being a key component ${ }^{2,4}$. A prospective study of patients with DPAM treated with CRS/HIPEC has shown a five- and 10-year survival of $80 \%$ and $75 \%$, respectively ${ }^{5-7}$ Similarly, treatment with CRS/HIPEC has been shown to confer a survival advantage in patients with high-grade appendiceal tumors $^{8-10}$. Because complete cytoreduction is the goal in treating patients with DPAM, it is essential to identify the presence of an undiagnosed patent processus vaginalis at the time of surgery, given that it may serve as a progression site. Therefore, hernia repair in the presence of DPAM may give rise to recurrence due to seeding of tumor cells at the time of repair.

It is reasonable to suggest that extension of DPAM to the scrotum may be attributed to either an unrecognized indirect inguinal hernia at the time of the initial surgery or to inadequate exposure of the hernia sac to the chemotherapeutic agent at the time of HIPEC. If a hernia is present in a DPAM patient, it is likely to result in tumoral metastasis to the hernial sac. Therefore, ruling out the presence of hernias during the physical examination, is extremely important. Furthermore, removal of the hernial sac is imperative during the surgical procedure.

We consider that the recurrence of mucinous neoplasm (DPAM) in the scrotum should be an indication for complete removal of all tumor and hyperthermic chemoperfusion. Herein, the same principles that are applied for intra-abdominal recurrence, like hernias, are a direct extension of the peritoneum.

In conclusion, increased awareness by surgeons of the coexistence of inguinal hernia with peritoneal neoplasm and the need for surgical repair is raised. CRS and HCS may be employed in treating patients with DPAM extension to the scrotum. Successful outcome is dependent on complete cytoreduction of metastatic tumor.

Conflict of Interest:

The authors declare no conflict of interest. This data has been previously presented at the $7^{\text {th }}$ International Symposium on Regional Cancer Therapies, Captiva Island, Florida, USA, February 18-20, 2012,

\section{References}

1. Ronnett BM, Zahn CM, Kurman RJ, Kass ME, Sugarbaker PH, Shmookler BM. Disseminated peritoneal adenomucinosis and peritoneal mucinous carcinomatosis. A clinicopathologic analysis of 109 cases with emphasis on distinguishing pathologic features, 
site of origin, prognosis, and relationship to "pseudomyxoma peritonei”. Am J Surg Pathol. 1995; 19(12): 1390-408.

2. Chua TC, Moran BJ, Sugarbaker PH, Levine EA, Glehen O, Gilly FN, et al. Early and long-term outcome data of patients with pseudomyxoma peritonei from appendiceal origin treated by a strategy of cytoreductive surgery and hyperthermic intraperitoneal chemotherapy. J Clin Oncol. 2012; 30: 2449-56.

3. Mohamed F, Cecil T, Moran B, Sugarbaker PH. A new standard of care for the management of peritoneal surface malignancy. Curr Oncol. 2011; 18(2): e84-e96.

4. Shankar S, Ledakis P, El Halabi H, Gushchin V, Sardi A. Neoplasms of the appendix: current treatment guidelines. Hematol Oncol Clin North Am. 2012; 26(6): 1261-90.

5. Omohwo C, Nieroda CA, Studeman KD, Thieme H, Kostuik P, Ross AS, et al. Complete cytoreduction offers longterm survival in patients with peritoneal carcinomatosis from appendiceal tumors of unfavorable histology. J Am Coll Surg. 2009; 209(3): 308-12.

6. Chua TC, Yan TD, Smigielski ME, Zhu KJ, Ng KM, Zhao $\mathrm{J}$, et al. Long term survival in patients with pseudomyxoma peritonei treated with cytoreductive surgery and perioperative intraperitoneal chemotherapy: 10 years of experience from a single institution. Ann Surg Oncol. 2009; 16(7): 1903-11.
7. Youssef H, Newman C, Chandrakumaran K, Mohamed F, Cecil TD, Moran BJ. Operative findings, early complications, and long-term survival in 456 patients withPseudomyxoma peritoneisyndrome of appendiceal origin. Dis Colon Rectum. 2011; 54(3): 293-9.

8. El Halabi H, Gushchin V, Francis J, Athas N, Macdonald R, Nieroda $\mathrm{C}$, et al. The role of cytoreductive surgery and heated intraperitoneal chemotherapy (CRS/ HIPEC) in patients with high-grade appendiceal carcinoma and extensive peritoneal carcinomatosis. Ann Surg Oncol. 2012; 19(1): 110-4.

9. Halabi HE, Gushchin V, Francis J, Athas N, Macdonald R, Nieroda C, et al. Prognostic significance of lymph node metastasis in patients with high-grade appendiceal cancer. Ann Surg Oncol. 2012; 19(1): 122-5.

10. Zhu KJ, Morris DL. Primary peritonectomy/ HIPEC for disseminated peritoneal adenomucinosis achieves much lower recurrence rates and better survival than secondary procedures. Surgeon. 2009; 7(6): 345-50. 